\title{
OCCURRENCE OF DIODON EYDOUXII (ACTINOPTERYGII: TETRAODONTIFORMES: DIODONTIDAE) IN THE AZORES AND COMPARISON WITH PACIFIC SPECIMENS
}

\author{
João P. BARREIROS ${ }^{1^{*}}$ and Ronald FRICKE ${ }^{2,3}$ \\ ${ }^{1}$ CE3C - Centre for Ecology, Evolution and Environmental Changes / Azorean Biodiversity Group, \\ University of the Azores, 9700-042 Angra do Heroismo, Portugal \\ ${ }^{2}$ Im Ramstal 76, 97922 Lauda-Königshofen, Germany \\ ${ }^{3}$ Staatliches Museum für Naturkunde Stuttgart, Rosenstein 1, 70191 Stuttgart, Germany (temporarily out of office)
}

Barreiros J.P., Fricke R. 2015. Occurrence of Diodon eydouxii (Actinopterygii: Tetraodontiformes: Diodontidae) in the Azores and comparison with Pacific specimens. Acta Ichthyol. Piscat. 45 (1): 101-102.

\begin{abstract}
A specimen of porcupine fish was collected by a fisherman at Terceira Island, Azores (north-eastern Atlantic), and identified as the pelagic porcupinefish, Diodon eydouxii Brisout de Barneville, 1846, a species recently recorded for the first time from the Azores. This record, together with an examination of the first reported specimen, allowed us to compare the external morphology with Pacific specimens. The possibility of this species to be relatively common in the Azores is discussed.
\end{abstract}

Keywords: pelagic porcupine fish, north-eastern Atlantic, Azorean Archipelago

The porcupine fish genus Diodon comprises 5 species (Eschmeyer 2014): Diodon hystrix Linnaeus, 1758; Diodon eydouxii Brisout de Barneville, 1846; Diodon holocanthus Linnaeus, 1758; Diodon liturosus Shaw, 1804; and Diodon nicthemerus Cuvier, 1818. Diodon hystrix and $D$. eydouxii form a pair of closely related species - similar to D. holocanthus and D. liturosus which form a second pair and differ from the first one with respect to body roundness. The fifth species $-D$. nicthemerus is a round-bodied species, which differs from the others in meristic characteristics and spination (Leis 2006).

Until recently, the only species of Diodon known from the north-eastern Atlantic was D. hystrix (see Tortonese 1986), and already registered in the Azores (Santos et al. 1997). Porteiro et al. (2010) reported the first occurrence of D. holocanthus in the Azores and treated D. eydouxii as "undetermined" because information is insufficient to establish their occurrence type or residency pattern. Yet, in 1984 and 2004 Diodon eydouxii, a circumtropical species more abundant in the eastern Pacific and thought to be restricted to the western Atlantic (Leis 1978), has been recorded, respectively, in Spain and the Azores in the north-eastern Atlantic (see Leis 2006).

In this note we report potentially important new information on the apparently erratic distribution of Diodon eydouxii in the Atlantic. On 29 March 2004, an adult specimen of porcupine fish was caught on hook and line near the surface, 5 NM SE off Praia da Vitória, Terceira Island, Azores (F/V Paulo Guitas). This is the second specimen recorded in the area, the first one being collected in São Miguel Island (see Azevedo et al. 2004). The morphometric and meristic data were examined and compared with those provided in Leis $(2002,2006)$; the specimen was positively identified as the pelagic porcupine fish, Diodon eydouxii Brisout de Barneville, 1846 accordingly to Leis (2006). This specimen was examined for gonad development and determination of both GSI and HIS as well as for stomach contents in DCA/UA anatomy laboratory. The specimen is deposited in the Ichthyological Collection of the DCA/UA (Universidade dos Açores), in Angra do Heroísmo, under the number 2002/04/DCA-UA (Fig. 1).

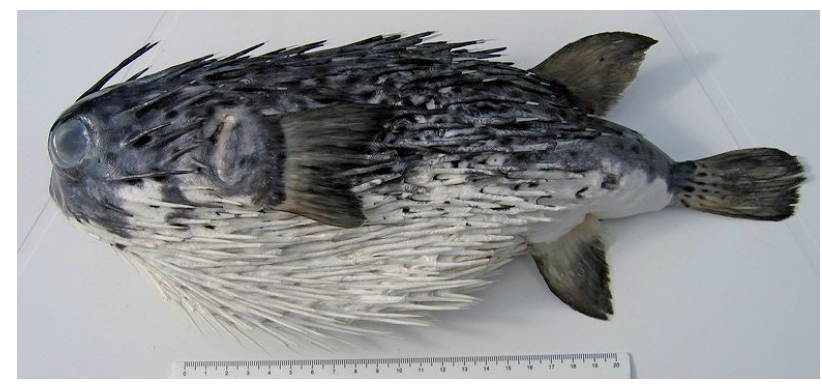

Fig. 1. The specimen of Diodon eydouxii caught off Praia da Vitória, Terceira Island, Azores (NE Atlantic); 2002/04/DCA-UA. 34.5 cm (TL); Photo by João P. Barreiros

\footnotetext{
* Correspondence: Dr. João P. Barreiros, Departamento de Ciências Agrárias, Universidade dos Açores, $9700-042$ Angra do Heroísmo, Portugal, phone: +351965691616, e-mail: (JPB) joaopedro@uac.pt, (RF) ronfricke@web.de.
} 
Morphometric and meristic characteristics of the specimen include: Body spines erectile with 2 roots, 2 spines dorsally wholly on caudal peduncle, $34.5 \mathrm{~cm}$ total length, $28 \mathrm{~cm}$ standard length (SL), $9.3 \mathrm{~cm}$ head length (3.01 times in SL), dorsal and anal fin pointed, 20 pectoral-fin rays, 16 anal-fin rays, 10 spines between the lower jaw and the anus; total weight $994.6 \mathrm{~g}$.

Both specimens from the Azores were dissected for stomach content and gonad analyses. Both had empty stomachs and were adult females in a temporary break of their gonadic development. Gonadosomatic (GSI) and hepatosomatic (HSI) indices assumed the following values:

- for specimen No. 1: GSI $=0.0024, \mathrm{HSI}=0.0694$;

- for specimen No. 2: GSI $=0.0090 ;$ HSI $=0.0914$.

These values indicate an increased liver weight typical of a reproductive resting period.

On 24 July 2002 the first record of Diodon eydouxii for the north-eastern Atlantic was reported (see Azevedo et al. 2004). Both Azorean specimens clearly differ in their colouration from the Pacific form, especially concerning the marked distinction between the white belly and the dark blue back, which is not so well defined in Pacific specimens (Froese and Pauly 2014). It is also visible that the Azorean specimens have longer spines than those from the Pacific. The Pacific form may represent a distinct species; more material is needed to examine a possible separation in the future. In that case, Diodon eydouxii would be the valid name for the eastern Pacific populations, while Diodon bertolettii de Lema, de Lucena, Saenger et De Oliveira, 1979, considered a junior synonym of the former by Leis (1986) without explanation, should be re-established for the Atlantic populations since it is probably a valid species. Only a few western Atlantic specimens and none south Atlantic ones were seen by Leis (2006).

Usually, Diodon species are pelagic only in their juvenile stages and are solitary; however the porcupine fish D. eydouxii is essentially pelagic and forming schools (Leis 1978). This schooling behaviour, associated with the recent occurrence of two specimens in two different Azorean islands suggests that the species is probably more common in this area than previously thought and more captures are certainly to be expected. Thus, special attention is to be given to surface long-line fisheries bycatch in order to increase the chance of collecting more D. eydouxii specimens and therefore to contribute in a better understanding of their ecological role in this part of the north-eastern Atlantic.

At a first glance, this note suggests an erratic/occasional occurrence of Diodon eydouxii in this area. However, we think that the species is more common than it appears due to its pelagic habits. A possible explanation for its apparent rarity may reside in misidentifications with $D$. hystrix and/or accidental catches being discarded at sea by local fishermen. This second specimen also raises the hypothesis of the species being in a process of establishing itself around the Azorean islands.

\section{ACKNOWLEDGEMENTS}

We are grateful to António Moutinho for presenting us the specimen, and to Paulo Guitas, Captain of F/V Paulo Guitas.

\section{REFERENCES}

Azevedo J.M.N., Raposeiro P.M., Rodrigues L. 2004. First record of Fistularia petimba and Diodon eydouxii for the Azores, with notes on the occurrence of three additional species. Journal of Fish Biology 65 (4): 1180-1184. DOI: $10.1111 / \mathrm{j} .0022-1112.2004 .00523 . \mathrm{x}$

Eschmeyer W.E. (ed.) 2014. Catalogue of fishes. Online version, updated 31 October 2014. California Academy of Sciences, San Francisco, CA, USA.

Froese R., Pauly D. (eds.) 2014. FishBase. [version 04/2014] http://www.fishbase.org

Leis J.M. 1978. Systematics and zoogeography of the porcupinefishes (Diodon, Diodontidae, Tetraodontiformes), with comments on egg and larval development. Fishery Bulletin 76 (3): 535-567.

Leis J.M. 1986. Family No. 269: Diodontidae. Pp. 903-907. In: Smith M.M., Heemstra P.C. (eds.) Smith's Sea Fishes. Macmillan, Johannesburg, Republic of South Africa.

Leis J.M. 2002. Diodontidae. Porcupinefishes. Pp. 2007-2013. In: Carpenter K.E. (ed.) FAO Species Identification Guide for Fishery Purposes and American Society of Ichthyologists and Herpetologists Special Publication No. 5. The living marine resources of the Western Central Atlantic. Vol. 3: Bony fishes part 2 (Opistognathidae to Molidae), sea turtles and marine mammals. FAO, Rome.

Leis J.M. 2006. Nomenclature and distribution of the species of the porcupinefish family Diodontidae (Pisces, Teleostei). Memoirs of Museum Victoria 63 (1): 77-90.

Porteiro F.M., Menezes G.M., Afonso P., Monteiro J.G., Santos R.S. 2010. Peixes marinhos (Chondrichthyes, Actinopterygii). [Marine fish (Chondrichthyes, Actinopterygii).] Pp. 331-344. In: Santos R.S. (Coordinator) Lista dos vertebrados marinhos (Chordata). [List of marine vertebrates (Chordata).] Pp. 325-345. In: Borges P.A.V., Costa A., Cunha R., Gabriel R., Gonçalves V., Martins A.F., Melo I., Parente M., Raposeiro P., Rodrigues P., Santos R.S., Silva L., Vieira P., Vieira V. (eds.) Listagem dos organismos terrestres e marinhos dos Açores. [A list of the terrestrial and marine biota from the Azores.] Principia Editora, Cascais, Portugal. [In Portuguese and English.]

Santos R.S., Porteiro F.M., Barreiros J.P. 1997. Marine fishes of the Azores: An annotated checklist and bibliography: A catalogue of the Azorean ichthyodiversity. ArquipélagoLife and Marine Sciences. Bulletin of the University of the Azores Supplement 1.

Tortonese E. 1986. Diodontidae. Pp. 1346-1347. In: Whitehead P.J.P., Bauchot M.-L., Hureau J.-C., Nielsen J., Tortonese E. (eds.) Fishes of the north-eastern Atlantic and Mediterranean Vol. 3. UNESCO, Paris.

Received: 18 May 2014 Accepted: 25 November 2014 Published electronically: 31 March 2015 